\title{
ВПРОВАДЖЕННЯ ІННОВАЦІЙНИХ ТЕХНОЛОГІЙ У ВИКЛАДАННЯ НАВЧАЛЬНОЇ ДИСЦИПЛІНИ НА КАФЕДРІ ЗАГАЛЬНОЇ ХІРУРГІЇ
}

\author{
P. O. Gerasymchuk, A. V. Pavlyshyn, D. B. Fira \\ I. Horbachevsky Ternopil National Medical University \\ IMPLEMENTATION OF INNOVATIVE TECHNOLOGIES OF TEACHING \\ AT THE DEPARTMENT OF GENERAL SURGERY
}

\begin{abstract}
Анотація. У статті наведено основні відомості про організацію навчання на кафедрі загальної хірургії з впровадженням новітніх технологій навчання по хірургічній спеціальності.

Головні елементи навчального процесу на сучасному етапі, такі, як опитування, лекція, бесіда, розповідь, інструктаж, у більшості випадків, виключають можливість активної участі всіх студентів у навчанні, не мотивують їх, та не враховують необхідності відпрацювання практичних навичок. Це обумовлює необхідність докорінних змін в організації та проведенні практичних занять на клінічних кафедрах. Досягнути відповідних результатів дозволяє впровадження в навчальний процес студентів новітніх та інтерактивних технологій навчання, арсенал яких на сучасному етапі поповнився значною кількістю методик. Ці технології перетворюють заняття в цікаву гру з залученням всіх студентів до спільної роботи та мотивуючи їх до навчання. Тому в цих умовах набуває актуальності використання симуляційних манекенів з метою навчання студентів певних навичок надання медичної допомоги, які потребують швидкої реакції і прийняття рішення, особливо в ургентних ситуаціях. Проведення занять із використанням наведених у статті методик вимагає від студента всебічної підготовки, 3 ретельним опрацюванням навчальних матеріалів на етапі підготовки. Отже, без відповідного базового багажу знань студент не зможе брати участь у занятті, на якому використовуються інтерактивні технології навчання.

Внаслідок проведеного аналізу автори дійшли висновків, що відпрацювання теми занять із використанням новітніх інтерактивних технологій, і в умовах, максимально наближених до клінічних, дозволяє студентам відпрацювати та оволодіти відповідними практичними навичками по обстеженню і наданню медичної допомоги хворим при загальнохірургічних захворюваннях, з формуванням клінічного мислення та відповідних професійних компетентностей.
\end{abstract}

Ключові слова: медичний вуз; новітні технології; інтерактивне навчання; загальна хірургія.

Abstract. The article provides basic information about the organization of teaching at the Department of General Surgery with the introduction of the latest teaching technologies in the surgical specialty.

The main elements of the educational process at the present stage such as surveys, lectures, conversations, stories, briefings, in most cases, eliminate the possibility of active participation of all students in learning, do not motivate them and do not take into account to working off the necessary practical skills. This necessitates radical changes in the organization and conduct of practical classes at clinical departments. To achieve the relevant results allows the introduction in the educational process of students the latest and interactive learning technologies, whose arsenal at the present stage has been replenished with a significant number of methods. These technologies convert classes into an interesting game with the involvement of all students in joint work and motivating them to study. Therefore, in these conditions, the use of simulation mannequins becomes relevant in order to teach students certain skills in providing medical care, which require a quick response and decision making, especially in urgent situations. Conducting classes using the methods described in the article, requires comprehensive training from the student, with careful study of educational materials at the stage of preparation. Thus, without basic knowledge, the student will not be able to participate in a lesson that uses interactive learning technologies.

() П. О. Герасимчук, А. В. Павлишин, Д. Б. Фіра 
As a result of the analysis, the authors came to the conclusion that working out the topic of classes using the latest interactive technologies, and in conditions as close as possible to clinical, allows students to develop and master relevant practical skills in examining and providing care to the patients with general surgical diseases, with the formation of clinical thinking and relevant professional competencies.

Key words: medical university; latest technologies; interactive training; general surgery.

Вступ. В умовах постійних змін соціально-економічних умов суспільства відбуваються і певні зміни у вищій медичній освіті. Для того щоб студенти-медики змогли оволодіти якісними інтелектуальними та професіональними навичками, слід переглянути методи, технології і зміст вищої медичної освіти, змінивши навчально-методологічні підходи до педагогічного процесу, що повинно як найбільше сприяти студентам на шляху здобування професійних знань. Оптимізація навчального процесу на клінічній кафедрі, підвищення теоретичної та практичної підготовки студентів є актуальним завданням вищих освітніх медичних навчальних закладів, на основі розробки і впровадження середників, методів і технологій навчання з орієнтацією на його індивідуалізацію та інтенсифікацію $[5,13]$.

На сучасному етапі лікар повинен володіти сформованим клінічним мисленням, вміти здійснювати всебічний аналіз отриманої інформації та проводити її диференціацію з метою вирішення складних медичних проблем. Здобути такий досвід студент може лише на основі впровадження в навчальний процес новітніх та інтерактивних форм і методів навчання, які передбачають активну участь студента в навчальному процесі. Ці методики грунтуються на активній пізнавально-навчальній роботі студента, що дозволяє стимулювати його внутрішню мотивацію; підвищувати пізнавальний інтерес; формувати самостійність; розвивати творчі властивості; створювати умови для самовизначення студента в професійному освітньому середовищі; розвивати його комунікативні навички; спонукати студентів до активної розумової і практичної діяльності в процесі засвоєння матеріалу [4, 6, 7, 11].

Саме використання нових освітніх технологій та інтерактивних методів навчання передбачають тісну взаємодію між викладачем та студентами і дозволяють сумісно моделювати ситуації, приймати відповідні рішення по їх вирішенню, оцінювати сумісні дії та дії кожного учасника навчального процесу в умовах реальної атмосфери ділової співпраці. Така методика викладання клінічної дисципліни дозволяє збільшити інтерес студентів до навчання, підвищити їх мотивацію, та покращити засвоєння навчального матеріалу, з активним відпрацюванням відповідних практичних навичок [1, 3].
Мета статті - на основі аналізу літературних джерел та власного досвіду провести аналіз використання новітніх та інтерактивних технологій, їх впливу на засвоєння навчального матеріалу студентами 3-го курсу на практичних заняттях по предмету «Загальна хірургія».

Теоретична частина. Викладення навчального матеріалу із загальної хірургії, як і з інших клінічних дисциплін, проходить в умовах швидкого прогресу хірургії, впровадження новітніх методик діагностики та лікування різних патологічних станів. Головним елементом навчального процесу на сучасному етапі залишаються такі методи навчання, як опитування, лекція, бесіда, розповідь, інструктаж. На жаль, ці методики, в більшості випадків, виключають можливість активної участі всіх студентів у навчанні, не мотивують їх та не враховують необхідності відпрацювання практичних навичок. Це обумовлює необхідність докорінних змін в організації та проведенні практичних занять на клінічних кафедрах.

Досягнути відповідних результатів дозволяє впровадження в навчальний процес студентів новітніх та інтерактивних технологій навчання, арсенал яких на сучасному етапі поповнився значною кількістю методик. Саме їх використання дозволяє значно покращити ефективність навчання [1, 3-6, 11].

3 метою підготовки студентів до практичного заняття на сайті кафедри в розділі «Навчальний процес» розміщені всі необхідні матеріали для кожного факультету, які включають електронні версії матеріалів підготовки до практичних занять та лекцій, контрольні питання для визначення початкового рівня знань, методичні рекомендації, рекомендована література. Окрім того, студенти можуть перевірити свій рівень підготовки шляхом проведення тестового контролю в системі Intranet moodl університету. $€$ також тестові питання відкритого типу без варіантів відповідей, що стимулює активний пошук інформації по темі і більш повне засвоєння матеріалу.

На кафедрі загальної хірургії, як і на будь-якій клінічній кафедрі, найкращий метод оволодіння професійними компетенціями лікаря та їх відпрацювання - це безпосередня робота з хворими, робо- 
та в перев’язувальних, операційних, процедурних, діагностичних кабінетах, під наглядом викладача або кваліфікованого лікаря-клініциста. Вона дозволяє максимально наблизити освітній процес до різних клінічних ситуацій, а студентам - відпрацювати комунікативні та практичні навички роботи 3 хворими. Однак така організація заняття має обмежене використання за рахунок невідповідного рівня практичної підготовки студентів, особливо на початкових курсах. Це може нести в собі високий ризик заподіяння шкоди хворому і виникнення у нього ускладнень. А навчання студентів правильної діагностики та надання допомоги реальним пацієнтам при загрозливих для життя станах стає дуже важким, а інколи і неможливим завданням. Також концепція сучасної страхової медицини надає можливість хворим відмовитися від участі студентів у лікувально-діагностичному процесі, не допускає студентів до виконання певних діагностичних та лікувальних маніпуляцій.

Тому в цих умовах набуває актуальності використання новітніх активних технологій навчання та симуляційних манекенів з метою навчання студентів певних навичок надання медичної допомоги, які потребують швидкої реакції і прийняття рішення, особливо в ургентних ситуаціях (тимчасова зупинка кровотечі, транспортна іммобілізація, серцеволегенева реанімація тощо).

Використання активних технологій навчання також набуває своєї актуальності при вивченні тих тем загальної хірургії, при яких можуть бути відсутні в клініці тематичні пацієнти (правець, газова гангрена, електротравма, вогнепальні поранення тощо). В таких випадках слід демонструвати студентам відповідні навчальні фільми, мультимедійні презентації, кольорові прозірки, навчальні стенди, діагностичні методики з широким залученням мережі «Інтернет» та інших комп’ютерних технологій.

Необхідно 1-2 практичних заняття проводити в умовах поліклініки, де студенти мають змогу ознайомитися з організацією амбулаторної хірургічної допомоги, бути присутніми на амбулаторному прийомі хворих, вивчити правила заповнення медичної документації, видачі листків тимчасової непрацездатності та ін.

Плануючи проведення практичного заняття, викладач повинен враховувати тематику та вид заняття (практичне, теоретичне заняття або самостійна робота), час заняття, технічну оснащеність аудиторії, можливість підключення до локальної мережі вузу та Інтернету, можливості клінічної бази, наявність тематичних хворих. Таке планування дозволяє вибрати найбільш оптимальну схему проведення заняття з максимальним забезпеченням технічними середниками та клінічним матеріалом.

У загальному практичну частину заняття можна поділити на такі етапи, як: брифінг - коротка інформація про практичну навичку, з викладенням основних положень, показань та протипоказань до даної лікувально-діагностичної маніпуляції; демонстрація маніпуляції викладачем; відпрацювання практичної навички студентами на фантомах і симуляторах під контролем викладача. Заключним етапом є дебрифінг - обговорення дій і отриманих результатів, з можливістю за потреби повторити навичку.

Арсенал сучасних новітніх технологій на сучасному етапі поповнився значною кількістю методик, використання яких дозволяє значно покращити ефективність навчання, навіть за умови відсутності тематичних хворих. Ці технології перетворюють заняття в цікаву гру із залученням всіх студентів до спільної роботи та мотивуючи їх до навчання [1, 2, 6, 8-10, 12].

Найбільш доступні та ефективні методи сучасного інноваційного навчання, які можна ефективно використовувати при проведенні практичних занять на клінічній кафедрі, такі:

1. Вирішення творчих завдань шляхом створення студентами мультимедійних презентацій, альбомів або стендів по заданій навчальній темі.

2. Інтерактивні виступи під час практичного заняття. Студент представляє свою доповідь на задану тему з мультимедійним супроводом, використовує інші наочні посібники, веде активний діалог з одногрупниками ставлячи їм питання та отримуючи на них відповіді.

3. Робота в малих групах. Студенти розділяються на групи по 4-5 чоловік, та отримують певне практичне завдання. Це дає можливість усім студентам брати активну участь у теоретичному вирішенні поставленого завдання, визначення об’єму надання медичної допомоги, та відпрацюванні конкретних практичних навичок, із формуванням комунікативних навичок та покращенням міжособистісного спілкування при командній роботі.

4. Ділові ігри, які дозволяють змоделювати конкретні клінічні ситуації. Це дає змогу студентам розвивати своє критичне мислення, комунікативні навички, відпрацьовувати різні варіанти вирішення проблемних ситуацій. У ході ділової гри можна відпрацьовувати окрему навичку (укладання бікса, одягання стерильного халата, перед- 
стерилізаційна обробка інструментарію тощо), комплекс навичок (тимчасова зупинка кровотечі, проведення серцево-легеневої реанімації на тренажері), демонструвати певну практичну навичку тощо. В етапи підготовки ділової гри входять вибір теми, яка повинна відповідати меті, розробка чіткого сценарію (плану), розподіл ролей. Студенти повинні знати, для чого введена кожна роль і чого вона може їх навчити. Гра проводиться більш успішно, якщо відповідним чином розподілені ролі, відпрацьована чітка схема гри і за її ходом слідкує викладач у ролі координатора ігрових дій. Обов'язковою умовою є підсумування результатів гри 3 аналізом допущених помилок.

5. Методика «Займи позицію». Вона дозволяє по відповіді студентів на поставлене питання швидко встановити в групі прихильників та противників тієї чи іншої позиції, та розпочати аргументоване обговорення дискусійного питання з точки зору обраної позиції.

6. Методика «ПОПН-формула». Дозволяє студенту аргументувати свою позицію по вирішенню дискутабельного питання шляхом використання таких чотирьох елементів, як: П - позиція, О - обгрунтування, П - приклад, $\mathrm{H}$ - наслідок.

7. Методика «Дерево рішень». Побудова такого дерева дозволяє опанувати навички вибору оптимального варіанта вирішення поставленого питання шляхом оцінки переваг та недоліків можливих варіантів. Вона є найбільш ефективною при виборі варіантів діагностики та лікувальної тактики стосовно певної патології.

8. Методика «мозкового штурму». Дозволяє згенерувати велику кількість варіантів відповідей на поставлене питання, та вибрати найбільш оптимальний хід вирішення проблемної ситуації. На першому етапі викладач пропонує проблему для обговорення, на другому - обговорюються всі можливі варіанти ії̈ вирішення, на третьому - вибирається оптимальний варіант вирішення проблеми.

9. Кейс-метод. Цей метод полягає в навчанні студентів на основі розбору та аналізу реальних клінічних ситуацій або вирішення ситуаційних задач: стандартних, критичних, екстремальних. Студентам пропонують розібрати та проаналізувати конкретні клінічні ситуації, розібратися в суті проблеми, запропонувати можливі варіанти вирішення і вибрати найкращі з них.

10. Групове обговорення. На першому етапі перед студентами ставиться певна проблема та виділяється певний час для пошуку аргументованих шляхів її вирішення. На другому етапі група студентів разом із викладачем проводить пошук оптимального методу вирішення проблеми. Це дозволяє досягнути кращої колективної комунікації студентів, навчає їх працювати в групі та покращує засвоєння навчального матеріалу.

11. Методика «Стандартизований пацієнт». Варіант активного навчання з моделюванням конкретної клінічної ситуації з використанням спеціально підготованого «стандартизованого пацієнта» з числа студентів, або акторів, які грають роль хворих за суворо визначеними сценаріями. Це виключає будь-яку імпровізацію, та моделює захворювання відповідно до його типової клінічної картини (кровотеча, перелом, вивих тощо). Завдання студента/ів полягає в проведенні обстеження хворого, постановки діагнозу та визначення тактики лікування, 3 відпрацюванням конкретних практичних навичок.

12. Ділова гра. Вона занурює студентів в атмосферу інтелектуальної діяльності, яка дуже близька до професійної діяльності лікаря в діагностиці захворювань, лікуванні хворих, змушує думати в режимі «тут і зараз», залежно від подій у грі. Крім того, студент залишається один на один зі своїм «хворим», несучи за нього всю відповідальність, що вигідно відрізняє цю гру від звичайної курації хворого. Дане навчання розвиває індивідуальні творчі здібності студента, вчить його правильно реагувати, самостійно оцінювати і вирішувати критичні ситуаційні задачі, з якими він буде стикатися у своїй професійній діяльності, розвиває комунікативні та професійні навички [6].

13. Використання симуляційних фантомів та манекенів. Цей метод дозволяє студентам відпрацювати окремі практичні навички або комплексне надання медичної допомоги при відповідних клінічних ситуаціях. Він має цілий ряд переваг, такі, як: можливість вибору складності завдання, відсутність ризиків для хворого та студентів; необмежена кількість повторів та необмежена тривалість навчання, що дозволяє отримати відповідний кінцевий результат; дає можливість ефективно відпрацювати дії при рідких клінічних ситуаціях; зменшення стресових ситуацій та реакцій для студентів при виконанні певних маніпуляцій та прийомів; дозволяє об'єктивізувати рівень засвоєння практичної навички; сприяє відпрацюванню взаємодії в команді, та злагоджених дій в екстрених ситуаціях. У цей час викладач має змогу здійснювати динамічний контроль за ходом заняття, визначати помилки та проводити їх відповідну корекцію.

Використовувати в процесі навчання можна як прості засоби (манекен руки для ушивання рани, 
манекен рани для проведення первинної хірургічної обробки та ін.), так і складні комп’ютеризовані манекени з моделюванням складних патологій і максимально реалістичних відповідей, які імітують реакції живої людини (наприклад серцево-легенева реанімація). Оцінка, яку отримує студент на симуляторі, є найбільш об’єктивною та незалежною, віддзеркалюючи набутий студентом досвід.

Проведення занять із використанням вищеозначених методик вимагає від студента всебічної підготовки, з ретельним опрацюванням навчальних матеріалів на етапі підготовки. Тому що без відповідного базового багажу знань студент не зможе брати участь у занятті, на якому використовуються активні технології навчання.

При проведенні практичного заняття можна використовувати й інші інноваційні технології навчання. В цих умовах завдання викладача - вибрати найбільш ефективні методики, відповідно до теми, та за можливості забезпечити максимально можливий контакт студентів із реальними хворими. Це дозволяє студентам ще на початкових курсах розбирати на практиці реальні клінічні ситуації, та за можливості відпрацьовувати відповідні практичні навички (комунікативні навички, суб’єктивне та об’єктивне обстеження хворого, участь у виконанні певних діагностично-лікувальних маніпуляцій перев’язки, зондування шлунка, ендоскопічне обстеження тощо).

Саме відпрацювання теми заняття з використанням новітніх технологій, та в максимально наближених до клінічних умовах, дозволяє студентам оволодіти й засвоїти відповідний теоретичний матеріал та практичні навички, з формуванням комунікативних навичок, клінічного мислення і відповідних професійних компетентностей.

Як показало опитування студентів на кафедрі, саме використання інноваційних технологій навчання, з їх активним залученням до навчального процесу, покращує доступність матеріалу, сприяє критичному осмисленню та систематизації знань, розвиває клінічне мислення, значно стимулює цікавість до вивчення дисципліни (96 \% опитаних).

\section{Список літератури}

1. Иванченко М. А. Активные и интерактивные методы обучения в высшей школе / М. А. Иванченко // Гуманитарные и социальные науки. - 2014. - № 2. С. 373-377.

2. Интерактивные методы обучения в медицинском вузе / Н. Д. Сергеева, И. Ю. Данилова, Т. К. Шкавро, Л. Р. Колесникова // Система менеджмента качества: опыт и перспективы. - 2016. - Вып. 5. - С. 44-47.
У кінцевому результаті це дозволяє студентам сформувати відповідну базу як теоретичних знань, так і практичних навичок із дисципліни.

Висновки та перспективи подальших досліджень. Використання методів і засобів інтерактивних форм навчання дозволяє оптимізувати викладання клінічної дисципліни на кафедрі, дає можливість зацікавити студентів, урізноманітнити заняття 3 дисципліни, створити комфортні умови для навчання, з акцентом на самостійну практичну роботу студентів. Це $є$ необхідною умовою забезпечення ефективності навчального процесу. Інтерактивні форми навчання створюють об’ єктивні передумови для формування професійного клінічного мислення студентів, сприяють їх професійно-особистому розвитку, стимулюють навчально-пізнавальні активності, та оволодіння навичками всебічного аналізу ситуацій, сприяють оперативному прийняттю самостійного рішення, оволодінню та відпрацюванню практичних навичок, що є необхідним у підготовці лікарів практичної медицини. Також це сприяє розвитку у студентів навичок спілкування і взаємодії в малій групі, формуванню мотивації до міжособистісної взаємодії, та кращому засвоєнню як теоретичних знань, так і практичних навичок. Проводячи практичне заняття, слід максимально акцентувати увагу на роботі студентів безпосередньо з хворими, активно залучаючи їх до складання та реалізації діагностично-лікувальної програми.

У свою чергу, використання інтерактивних технологій потребує від викладача творчого підходу до організації, оптимізації та активації навчального процесу, з використанням найбільш оптимального їх поєднання.

Перспективи подальших досліджень повинні бути спрямовані на оцінку ефективності кожного методу інтерактивного навчання окремо, та при їх поєднанні, з формуванням оптимальних схем проведення практичних занять, і створення комплексу їх методичного забезпечення (відеофільми, фотографії, прозірки, вправи, завдання, тематичні засоби, муляжі, манекени тощо) відповідно до кожної теми дисципліни.

3. Ипатова Л. О. Активные методы обучения как важный фактор активизации учебного процесса в высшей школе / Л. О. Ипатова // ФӘН-Наука. - 2012. № 12. - С. 72-74.

4. Муравьев К. А. Симуляционное обучение в медицинском образовании - переломный момент / К. А. Муравьев, А. Б. Ходжаян, С. В. Рой // Фундаментальные исследования. - 2011. - № 10, ч. 3. - С. 534-537. 
5. Мухина Т. Г. Активные и интерактивные образовательные технологии (формы проведения занятий) в высшей школе : учебное пособие / Т. Г. Мухина. Н. Новгород : ННГАСУ, 2013. - 97 с.

6. Павляк А. Я. Досвід проведення практичного заняття з використанням інтерактивних методів формування професійних умінь у майбутніх медичних працівників / А. Я. Павляк // Медична освіта. - 2019. - № 1. С. 102-106.

7. Панфилова А. П. Инновационные педагогические технологии : учеб. пособие / А. П. Панфилова. - М. : Издательский центр «Академия», 2009. - 192 с.

8. Педагогические технологии / М. В. Буланова-Топоркова, А. В. Духавнева, В. С. Кукушкин, Г. В. Сучков. Ростов-на-Дону : Изд-во «Феникс», 2010. - С. 29-140.

\section{References}

1. Ivanchenko, M.A. (2014). Aktivnye i interaktivnye metody obucheniya v vysshey shkole [Active and interactive teaching methods in higher education]. Gumanitarnye $i$ sotsialnye nauki - Humanities and Social Sciences, 2, 373377 [in Russian].

2. Sergeeva, N.D., Danilova, I.Yu., Shkavro, T.K., \& Kolesnikova, L.R. (2016). Interaktivnye metody obucheniya $\mathrm{v}$ meditsinskom vuze [Interactive teaching methods in a medical school]. Sistema menedzhmenta kachestva: opyt $i$ perspektivy - Quality Management System: Experience and Prospects, 5, 44-47 [in Russian].

3. Ipatova, L.O. (2012). Aktivnye metody obucheniya, kak vazhnyy faktor aktivizatsii uchebnogo protsessa $\mathrm{v}$ vysshey shkole [Active methods of teaching as an important factor in the activation of the educational process in higher education]. FəN-Nauka - FəN-Science, 12, 72-74 [in Russian].

4. Muravev, K.A., Khodzhayan, A.B., \& Roy, S.V. (2011). Simulyatsionnoe obuchenie $\mathrm{v}$ meditsinskom obrazovanii - perelomnyy moment [Simulation training in medical education - a watershed moment]. Fundamentalnye issledovaniya - Fundamental Research, 10 (3), 534-537 [in Russian].

5. Mukhina, T.G. (2013). Aktivnye i interaktivnye obrazovatelnye tekhnologii (formy provedeniya zanyatiy) $v$ vysshey shkole: uchebnoe posobie [Active and interactive educational technologies (forms of conducting classes) in higher education: a textbook]. N. Novgorod: NNGASU [in Russian].

6. Pavliak, A.Ya. (2019). Dosvid provedennia praktychnoho zaniattia z vykorystanniam interaktyvnykh metodiv formuvannia profesiinykh umin u maibutnikh medychnykh pratsivnykiv [Interactive methods of professional skills разование, 2005.
9. Пометун О. І. Енциклопедія інтерактивного навчання / О. І. Пометун. - К., 2007. - 144 с.

10. Пометун О. I. Сучасний урок. Інтерактивні технології навчання : наук.-метод. посіб. / О. І. Пометун, Л. В. Пироженко ; за ред. О. І. Пометун. - К. : Видавництво А.С.К., 2004. - 192 с.

11. Романцов М. Г. Инновации в медицинском образовании посредством внедрения педагогических технологий / М. Г. Романцов, И. Ю. Мельникова // Успехи современного естествознания. - 2015. - № 2. - С.189-194.

12. Селевко Г. К. Энциклопедия образовательных технологий : в 2-х т. / Г. К. Селевко. - М. : Народное об-

13. Стандарти і рекомендації щодо забезпечення якості в Європейському просторі вищої освіти (SEG). - K. : ТОВ «ЦС», 2015.

during a practical lesson for future medical staff]. Medychna osvita - Medical Education, 1, 102-106 [in Ukrainian].

7. Panfilova, A.P. (2009). Innovatsionnye pedagogicheskie tekhnologii: ucheb. posobie [Innovative pedagogical technologies: textbook]. Moscow: Izdatelskiy tsentr «Akademiya» [in Russian].

8. Bulanova-Toporkova, M.V., Dukhavneva, A.V., Kukushkin, V.S., \& Suchkov, G.V. (2010). Pedagogicheskie tekhnologii [Pedagogical technologies]. Rostov na Donu: Izd-vo «Feniks» [in Russian].

9. Pometun, O.I. (2007). Entsyklopediia interaktyvnoho navchannia [Encyclopedia of interactive learning]. Kyiv [in Ukrainian].

10. Pometun, O.I., \& Pyrozhenko, L.V. (2004). Suchasnyi urok. Interaktyvni tekhnolohii navchannia: nauk.-metod. posibn. [A modern lesson. Interactive learning technologies: Scientific method. manual]. Kyiv: Vydavnytstvo A.S.K. [in Ukrainian].

11. Romantsov, M.G., \& Melnikova, I.Yu. (2015). Innovatsii $\mathrm{v}$ meditsinskom obrazovanii posredstvom vnedreniya pedagogicheskikh tekhnologiy [Innovations in medical education through the implementation of educational technology]. Uspekhi sovremennogo estestvoznaniya - The Successes of Modern Natural Science, 2, 189-194 [in Russian].

12. Selevko, G.K. (2005). Entsiklopediya obrazovatelnykh tekhnologiy. V 2-kh tomakh [Encyclopedia of educational technologies. In 2 volumes]. Moscow: Narodnoe obrazovanie [in Russian].

13. (2015). Standarty $i$ rekomendatsii shchodo zabezpechennia yakosti v Yevropeiskomu prostori vyshchoi osvity (SEG) [Standards and Guidelines for Quality Assurance in the European Higher Education Area (ESG)]. Kyiv: TOV “CS” [in Ukrainian].

Отримано 01.02.21

Рекомендовано 05.02.21 